DOI 10.15290/cnisk.2017.01.02.07

\author{
DR GRAŻYNA KĘDZIERSKA
}

Niepaństwowa Wyższa Szkoła Pedagogiczna w Białymstoku

\title{
Kobieca przemoc ekonomiczna w Polsce
}

\section{Streszczenie}

Początki zainteresowania przemoca ekonomiczna na świecie przypadaja na lata osiemdziesiate XX w., ale badania akademickie na ten temat, w niewielkim zreszta zakresie, podjęto dopiero dziesięć lat później. Przemoc ekonomiczna jest zjawiskiem psychologicznym, zachowaniem mającym na celu kontrolę zdolności partnerki lub partnera do nabywania, utrzymywania i korzystania $z$ zasobów ekonomicznych. Sprawca, obok kontroli finansowej, dąży do psychicznego uzależnienia, upokorzenia i manipulowania ofiara w celu jej podporzadkowania. Kata$\log$ działań obejmuje kilkanaście różnych zachowań przemocowych. Przemoc ekonomiczna nie pozostawia widocznych śladów i dlatego nazywa się ja „przezroczystym problemem”. Pojawia się w związkach określanych jako bliskie relacje, bez względu na sytuację materialna, wykształcenie i wiek. Ofiarami tej przemocy moga być partnerzy tworzacy związek, ale także osoby niedołężne ze względu na starość lub chorobę. Polskie badania ankietowe z lat 2010 i 2014 pokazuja, że sprawcami przemocy ekonomicznej sa też kobiety. W wyniku tych badań opisano przede wszystkim skalę zjawiska, opierając się na analizie deklaracji respondentów sklasyfikowanych w grupach świadków pośrednich, ofiar mężczyzn, sprawczyń kobiet oraz świadków bezpośrednich.

Słowa kluczowe: przemoc domowa • przemoc ekonomiczna • mężczyzna jako ofiara $\bullet$ kobieta jako sprawca 


\title{
FEMALE ECONOMIC VIOLENCE IN POLAND
}

\begin{abstract}
The idea of economic violence started to be widely discussed in 1980 s but the scientific research on the issue didn't appear until ten years later. Economic violence is a psychological phenomenon - a coercive behavior pattern intended to control the partner's ability to acquire, maintain and use economic resources. The main purpose of an abuser is to gain and maintain power over the partner by threatening the victims' security and ability to achieve economic independence. Various forms of economic abuse may generally coexist within the same relationship. This form of coercive behavior leaves no visible traces, and is therefore referred to as a "transparent problem". Economic violence often takes place between people in close relationships regardless of their material status, education and age, but may also affect elderly people because of their health problems or advanced age.

The results of Polish surveys conducted between 2010 and 2014 helped to highlight the scale of the problem and revealed that women are as likely to be abusive to men. The research was based on declarations of the respondents divided into the following groups: indirect witnesses, male victims, female abusers and direct witnesses.
\end{abstract}

Keywords: domestic violence - economic violence - male victims • female abusers

\section{Wprowadzenie}

Powszechnie uważa się, że agresja i stosowanie przemocy sa domena mężczyzn, kobiety natomiast charakteryzuje bezradność. Agresja ${ }^{1}$ u chłopców, a później mężczyzn, ma dużą dozę przyzwolenia społecznego, łączona jest $z$ siła i umiejętnościami wypełniania roli opiekuna rodziny, żywiciela zapewniajacego byt partnerce i dzieciom. Jak jednak pokazują liczne statystyki, kobiety też wy-

\footnotetext{
1 Agresja i przemoc nie sa synonimami. Agresja to wrogie, zaczepne zachowanie się, a przemoc określa się jako przewage wykorzystywana w celu narzucenia komuś swojej woli, wymuszenia czegoś na kimś (Słownik języka polskiego [Dostęp: 6.03.2017]. Dostępny w World Wide Web: <http://sjp.pwn.pl/sjp/przemoc; 2510670.html>).
} 
kazują zachowania przemocowe w stosunku do swoich partnerów i nie tylko².

Przez wieki społeczna rola kobiety koncentrowała się na sprawnym działaniu ogniska domowego, na wychowaniu dzieci. Również dzisiaj to przede wszystkim kobieta w przestrzeni domowej buduje więź rodzinną, małżeńską, macierzyńską, towarzyska i międzypokoleniowa. $Z$ kolei $\mathrm{w}$ przestrzeni publicznej rola społeczna kobiet znacznie się zmieniła. Jeśli sa aktywne w jakiejś profesji, potrafia łączyć obowiązki domowe i zawodowe, sa ambitne, obowiązkowe i skrupulatne, dobrze zorganizowane i maja podzielność uwagi. Charakteryzuja się odpowiedzialnościa materialną za rodzinę, a szczególnie za potomstwo, co oznacza, że starają się nie stracić pracy. Kobiety pracujące zawodowo mają wyższe poczucie wartości i są większym autorytetem dla swoich dzieci niż kobiety bierne zawodowo. Interesuja się praca partnera, sprawami kraju i świata, uczestnicza w życiu publicznym ${ }^{3}$. Mimo tych i jeszcze wielu innych atrybutów wykształconych w procesie socjalizacji kobieta wciąż ma gorsza pozycję niż mężczyzna w wielu obszarach aktywności społecznej i nadal mężczyznę się rozgrzesza, a kobietę piętnuje ${ }^{4}$.

Zacisze domowe pielęgnowane przez kobietę nierzadko bywa świadkiem rozgrywających się tam tragedii. Perspektywa związków międzyludzkich, jakie tworzą kobieta i mężczyzna, pokazuje, że tzw. przemoc domowa pod względem sprawczym w większości jest udziałem mężczyzn, ale także kobiet. Według statystyki kryminalnej (Tabela 1) od 2006 r. udział procentowy kobiet jako sprawczyń różnych form przemocy domowej ciagle wzrasta, przy czym ogólna liczba sprawców ma tendencję malejąca.

2 Porównaj P. Gotfryd, Kiedy bije kobieta. Doświadczenia brytyjskie, „Niebieska Linia” [online] 2010, nr 4 [Dostęp: 7.01.2017]. Dostępny w World Wide Web: $<$ http://bit.ly/2qFBc1G>.

3 A. Kotlarska-Michalska, Społeczne role kobiet, „Edukacja Humanistyczna” 2011, nr 1, s. 25 i n.

${ }^{4}$ K. Piątek, Być kobieta $w$ Polsce $w$ XXI wieku - blaski i cienie [w:] Między tradycja a nowoczesnościa. Wspótczesna kobieta polska z perspektywy socjologicznej, red. E. Jurczyńska-McCluskey, K. Piątek, Bielsko-Biała 2006, s. 17. 
Tabela 1. Sprawcy przemocy domowej w zależności od płci w Polsce w latach 2006-2016

\begin{tabular}{|c|c|c|c|c|c|}
\hline \multirow{2}{*}{ Rok } & \multicolumn{3}{|c}{ Liczba sprawców przemocy domowej } \\
\cline { 3 - 6 } & \multirow{2}{*}{ Ogółem } & Mężczyźni & Nieletni & \multicolumn{2}{c|}{ Kobiety } \\
\cline { 3 - 6 } & & & & $\begin{array}{c}\text { Udzial \% } \\
\text { wiczba } \\
\text { ogólnej } \\
\text { liczbie }\end{array}$ \\
\hline 2016 & 74155 & 68321 & 373 & 5461 & 7,36 \\
\hline 2015 & 76034 & 70484 & 306 & 5244 & 6,89 \\
\hline 2014 & 78489 & 72791 & 397 & 5301 & 6,75 \\
\hline 2013 & 61450 & 56755 & 255 & 4440 & 7,22 \\
\hline $2012 *$ & 51531 & 47728 & 281 & 3522 & 6,83 \\
\hline 2011 & 71914 & 68248 & 195 & 3471 & 4,82 \\
\hline 2010 & 83390 & 79204 & 205 & 3981 & 4,77 \\
\hline 2009 & 81472 & 77362 & 220 & 3926 & 4,81 \\
\hline 2008 & 86568 & 82425 & 201 & 3942 & 4,55 \\
\hline 2007 & 81743 & 77937 & 170 & 3632 & 4,44 \\
\hline 2006 & 96775 & 92526 & 175 & 4074 & 4,20 \\
\hline
\end{tabular}

* Od 2012 r. zmienił się system rejestracji statystycznej przemocy domowej, a liczby dotyczą wyłącznie działań podejmowanych przez Policję w procedurze Niebieskiej Karty.

Źródło: Statystyka - Policja. Przemoc w rodzinie. Dane za rok 2016 [Dostęp: 31.11.2016]. Dostepny w World Wide Web: <http://bit.ly/1nAcMjB>; obliczenia udziału procentowego - własne.

Kobieca przemoc istnieje od dawna. Kobiety plotkowały, obmawiały, płakały, wyrażając w ten sposób swoją złość. Zmiany zachodzące w społeczeństwie, w sposobie życia oraz współczesny poziom stresu sprawiaja, że takie zachowania nie sa wystarczajacym środkiem na tzw. odreagowanie. Kobiety stały się bardziej agresywne, ponieważ stawia im się wysokie wymagania. Aby móc funkcjonować we współczesnym świecie i mieć w nim przestrzeń 
dla siebie, stały się też bardzo silne. Zaprzeczają swojej delikatności i czułości, wyrażając agresję w sposób typowo męski ${ }^{5}$. Wbrew pozorom przemoc kobiet jest dość częsta i przybiera różne formy. Rozciaga się od „niewinnej kpiny”, „nieszkodliwego” poszturchiwania, zapomnienia po wyrafinowane niszczenie poczucia czyjejś wartości, uniemożliwienie zaspokojenia podstawowych potrzeb życiowych lub zabójstwo ${ }^{6}$.

W literaturze występuje kilka różnych klasyfikacji przemocy domowej7. Do klasycznie przyjmowanych kategorii zachowań przemocowych należą przemoc fizyczna, psychiczna i seksualna ${ }^{8}$. Kategoria przemocy ekonomicznej pojawia się dopiero w kontekście społeczno-politycznej analizy zagadnienia. Dokumentem sankcjonujacym istnienie tego rodzaju przemocy jest Konwencja Rady Europy z 11 maja 2011 r. sporzadzona w Stambule, zatytulowana Konwencja o zapobieganiu i zwalczaniu przemocy wobec kobiet $i$ przemocy domowej. $\mathrm{W}$ art. 3 Konwencji podano najważniejsze definicje, a wśród nich jest zapis że przemoc domowa oznacza wszelkie akty fizycznej, seksualnej, psychologicznej lub ekonomicznej przemocy występujace $\mathrm{w}$ rodzinie lub gospodarstwie domowym lub pomiędzy byłymi lub obecnymi małżonkami lub partnerami, niezależnie od tego, czy sprawca i ofiara dzielą

5 A. Kowalska, Słaba pleć? - Przemoc stosowana przez kobiety [w:] Przemocy mówimy dość, red. M.P. Krysiak, Maków Mazowiecki 2010, s. 103.

6 I. Pospiszyl, Przemoc w rodzinie, Warszawa 1998, s. 93.

7 Wszystkie proponowane $\mathrm{w}$ literaturze definicje przemocy domowej zawieraja wspólne elementy, charakteryzujace istote zjawiska, a mianowicie: 1) jest to działanie intencjonalne, świadome i zamierzone, mające na celu kontrolowanie i podporzadkowanie ofiary; 2) występuje przewaga siły ze strony agresora, sprawcy przemocy; 3) sprawca narusza prawa i dobra osobiste ofiary, godzi również w jej wolność osobista; 4) zachowanie sprawcy wywołuje ból i cierpienie ofiary; 5) zachowanie sprawcy wykracza poza normy społeczne i zasady relacji interpersonalnych (G. Leśniewska, Przemoc ekonomiczna wobec kobiet - przeźroczysty problem [w:] Gospodarka przestrzenna: aktualne aspekty polityki spoleczno-gospodarczej $i$ przestrzennej, red. J. Potocki, J. Ladysz, Wrocław 2016, s. 220).

8 Fundacja Centrum Praw Kobiet, Przemoc $w$ rodzinie a wymiar sprawiedliwości, Warszawa 2005, s. 6-7 [Dostęp: 6.03.2017]. Dostępny w World Wide Web: $<$ http:// bit.ly/2qAzRKa>. 
miejsce zamieszkania, czy też nie 9 . Zapisy Konwencji stwarzaja ramy dla prawnego przeciwdziałania wszelkim formom przemocy domowej na poziomie europejskim, w szczególności wobec kobiet. Uznaje się, że ze względu na płeć kobiety i dziewczęta są bardziej narażone na przemoc niż mężczyźni i chłopcy, ale Konwencja ma być zastosowana do wszystkich ofiar przemocy domowej, niezależnie od płci. Obowiązuje zarówno w czasie pokoju, jak i w sytuacjach konfliktów zbrojnych. Zapewnia także specjalny mechanizm monitoringu, by zadbać o efektywne wdrożenie jej przepisów przez strony, które ja ratyfikowały. Polska podpisała tę Konwencję w grudniu 2012 r., ale ratyfikowano ja dopiero 6 lutego 2015 r. W literaturze przedmiotu przemoc ekonomiczna najczęściej umieszczana jest w obrębie przemocy psychicznej, występuje też jako odrębna kategoria zachowań obserwowanych w rodzinie ${ }^{10}$.

$\mathrm{Z}$ perspektywy personalnej przemoc $\mathrm{w}$ rodzinie dzieli się na tę wobec partnera (małżonki, małżonka) lub dziecka oraz wobec osób w podeszłym wieku11. Najczęściej ofiarami różnych form przemocy staja się dzieci i osoby starsze bądź chore. Ci członkowie rodziny są źle traktowani, ponieważ nie są w stanie się bronić. W stosunku do osób w podeszłym wieku przemoc finansowa polega na nieupoważnionym użyciu ich funduszy, własności prywatnej, tytułów własności i uprawnień będacych w posiadaniu seniora $^{12}$. Na skutek przemocy domowej cierpią też mężczyźni, mimo że ich zależność od partnerek nie jest tak oczywista jak

9 Konwencja Rady Europy, Konwencja o zapobieganiu i zwalczaniu przemocy wobec kobiet $i$ przemocy domowej, thumaczenie przygotowane na zlecenie Kancelarii Prezesa Rady Ministrów [Dostęp: 3.03.2017]. Dostępny w World Wide Web: <http:/ / bit.ly/2gRTPOU>.

10 J. Tracz-Dral, Przemoc ekonomiczna, opracowanie tematyczne OT-639, Kancelaria Senatu, Warszawa 2015, s. 3 [Dostęp: 6.03.2017]. Dostępny w World Wide Web: <http://bit.ly/2raz5GB>; Przemoc $w$ rodzinie wobec osób starszych $i$ niepełnosprawnych. Poradnik dla pracowników pierwszego kontaktu, red. D. Jaszczak-Kuźmińska, K. Michalska, Warszawa 2010 [Dostęp: 6.03.2017]. Dostępny w World Wide Web: <https://ms.gov.pl/Data/Files/_public/ppwr/poradnik.pdf>. ${ }^{11} \mathrm{~K}$. Browne, M. Herbert, Zapobieganie przemocy $w$ rodzinie, Warszawa 1999.

12 E. Sygit, R. Ossowski, Przemoc wobec osób starszych ze względu na ich wiek, płeć i wykształcenie, „Gerontologia Polska” [online] 2008, nr 3, s. 134-164 [Dostęp: 6.03.2017]. Dostępny w World Wide Web: <http://bit.ly/2sdtL3S>. 
w przypadku zależności dziecka od osoby dorosłej lub osoby starszej od opiekuna ${ }^{13}$.

Przemoc w związkach kobiety i mężczyzny występuje we wszystkich kręgach kulturowych i warstwach społecznych. Jest ona znaczacym fragmentem zjawiska określanego jako „przemoc w bliskich relacjach" i odnosi się do sytuacji przemocy między osobami pozostającymi w bliskim zwiąku formalnym lub nieformalnym bądź osobami, które uważają siebie za parę, nie zamieszkując jednak wspólnie. Przemoc wobec partnera lub partnerki jest bardzo złożonym problemem społecznym i obejmuje jej wszystkie formy, czyli przemoc psychiczna, fizyczna, wykorzystanie seksualne, jak i przemoc ekonomiczną ${ }^{14}$.

Ta ostatnia jest rodzajem przemocy psychicznej, manipulowaniem przewaga materialna w celu kontrolowania drugiej osoby. Sprawca, wykorzystując uzależnienie od środków finansowych, znęca się psychicznie nad współmałżonkiem lub dziećmi. Za pomocą finansów próbuje przejać kontrolę nad partnerem, całkowicie uzależniając go od siebie, izolując, pozbawiając elementarnych praw do decydowania o sobie. Zatem przemoc ekonomiczna pod względem definicyjnym to zachowanie majace na celu kontrole zdolności partnerki lub partnera do nabywania, utrzymywania $i$ korzystania z zasobów ekonomicznych. Zachowania te zagrażaja ekonomicznemu bezpieczeństwu i niezależności, służac podporzadkowaniu sobie partnera lub partnerki. W definicji konkretyzuja się trzy cechy przemocy ekonomicznej: kontrola, zdolność do korzystania $z$ zasobów oraz zagrożenie dla ekonomicznej niezależności ${ }^{15}$. Definicja ta w szczególności ma zastosowanie w przemocy w zwiazkach intymnych, pozostawiajacc na uboczu zjawisko występujące $\mathrm{w}$ relacjach $\mathrm{z}$ seniorami.

\footnotetext{
13 A. Lipowska-Teutsch, Rodzina a przemoc, Warszawa 1993, s. 6.

14 Ibidem.

15 A. Chełstowska, M. Druciarek, A. Niżyńska, Przemoc ekonomiczna w zwiazkach. Diagnoza zjawiska i dyskusja o przeciwdziałaniu, Warszawa 2015, s. 9-10; cyt. za: A.E. Adams, C.M. Sullivan, D. Bybee, M.R. Greeson, Development of the Scale of Economic Abuse, „Violence Against Women” 2008, Vol. 14, Iss. 5, p. 563 [Dostęp: 06.03.2017]. Dostępny w World Wide Web: <http://bit.ly/2qAaXyo>.
} 
Przejawy przemocy ekonomicznej układaja się w szeroki wachlarz nadużyć ekonomicznych, których ostatecznym celem jest utrzymanie dominacji i kontroli nad partnerem. Sprawca lub sprawczyni podejmuja takie działania, jak ${ }^{16}$ :

- uniemożliwianie lub ograniczanie dostępu do rodzinnych środków finansowych, np. do konta bankowego,

- ograniczanie możliwości podjęcia pracy zarobkowej,

- wydzielanie środków i skrupulatne kontrolowanie wydatków,

- przywłaszczanie środków przeznaczonych na utrzymanie rodziny,

- zmuszanie do podpisywania zobowiąań finansowych (kredyt, pożyczka, weksel),

- zmuszanie do składania fałszywych zeznań podatkowych,

- zmuszanie do upokarzającego żebrania o pieniądze,

- odmawianie prawa do posiadania środków finansowych na cele osobiste,

- zabieranie wynagrodzenia, kart kredytowych,

- zbywanie elementów wspólnego majątku bez wiedzy partnera,

- zbywanie osobistego majątku partnerki lub partnera bez jej lub jego wiedzy,

- zmuszanie do pracy bez wynagrodzenia w rodzinnej firmie,

- fikcyjne zatrudnienie partnera we własnej firmie,

- zakazywanie wykonywania pracy zawodowej,

- podejmowanie działań powodujących stratę pracy,

- niszczenie rzeczy osobistych,

- odmawianie pieniędzy na prowadzenie domu,

- odmawianie lub wręcz ukrywanie informacji o stanie finansowym rodziny,

- kontrolowanie dostępu do opieki zdrowotnej,

- zakazywanie lub utrudnianie dostępu do edukacji,

- wyłączenie $z$ podejmowania decyzji finansowych,

16 J. Tracz-Dral, op. cit., s. 3-4. 
- pozostawianie bez opieki osoby, która nie może samodzielnie zaspokoić niezbędnych potrzeb,

- zmuszanie do sprzedaży majątku osobistego ${ }^{17}$,

- uchylanie się od płacenia alimentów.

Partner lub partnerka czasem mieszka w wygodnym domu, jest dobrze ubrana, ale jednocześnie nie ma kontroli nad domowym budżetem, nie ma też wpływu na kluczowe dla rodziny decyzje finansowe, jak zakup samochodu, domu czy drobniejsze sprawunki. Sprawca lub sprawczyni przemocy ekonomicznej często uzależnia druga osobę od siebie, wmawiając jej, że jest bezwartościowa, ponieważ nie potrafi na siebie zarobić i wciąż siedzi $\mathrm{w}$ domu. Zastraszanie obejmuje np. utwierdzanie ofiary $\mathrm{w}$ przekonaniu, że nie poradzi sobie na rynku pracy, gdyż nic nie potrafi.

Stosowanie przemocy ekonomicznej jest tak samo upokarzające i niszczące, jak inne rodzaje przemocy. Ofiary rzadziej jednak szukaja pomocy u specjalisty lub organów ścigania. Sprawcy lub sprawczyni trudniej udowodnić winę, bo ta forma przemocy jest trudno dostrzegalna. Przemoc ekonomiczna to przezroczysty problem $^{18}$.

Przemoc ekonomiczna skutkuje kłopotami zdrowotnymi, ma negatywny wpływ na rynek pracy i gospodarkę, powoduje utrate wiary we własne kompetencje zawodowe, obniżenie samooceny, stany lękowe i depresję. U ofiar moga występować trudności $z$ panowaniem nad emocjami w sytuacjach stresujacych. Pozostawanie bez pracy to też brak środków finansowych na podnoszenie kwalifikacji i możliwość samodzielnego utrzymania. Innymi następstwami przemocy ekonomicznej są: bezradność, bierność, uwikłanie w przeszłość, niezdecydowanie, nieumiejętność podję-

17 Jedno $z$ działań zaliczone przez Centrum Praw Kobiet do przemocy ekonomicznej wobec kobiet (Od przemocy ekonomicznej do niezależności, red. M. Bladowska-Wrzodak [Dostęp: 07.01.2017]. Dostępny w World Wide Web: $<$ http://bit.ly/2qA83d8>).

18 Określenia „przezroczysty problem” używa G. Leśniewska (Eadem, op. cit., s. 219-225). 
cia decyzji, bierne zaniechanie samoobrony, brak bezpieczeństwa i wiary we własne siły, a nawet zespół stresu pourazowego ${ }^{19}$.

Początki zainteresowania przemocą ekonomiczna jako odrębną kategorią zachowań występujących w związkach datują się na pierwsza połowe lat osiemdziesiatych XX w. ${ }^{20}$ Jednak badania akademickie nad ta forma przemocy zainicjowano w USA dopiero pod koniec lat dziewięćdziesiątych. W 1999 r. przeanalizowano metody jakimi mężczyźni powstrzymuja kobiety od podejmowania edukacji i zatrudnienia oraz opisano przypadki odbierania kobietom ich zarobków, aby nie miały dostępu do żadnych źródeł finansowania niezależnych od sprawcy ${ }^{21}$. W Unii Europejskiej w latach 2011-2012 zrealizowano badania nad przemoca, w których jedno pytanie dotyczyło przemocy ekonomicznej. Okazało się, że $12 \%$ respondentek doświadczało ekonomicznych zachowań przemocowych. Najczęściej takie doświadczenia miały kobiety $z$ Bułgarii, najrzadziej Portugalki. Polki uplasowały się na poziomie średniej unijnej $z$ wynikiem $12 \% 22$.

W Polsce świadomość społeczna na temat przemocy ekonomicznej jest bardzo niska i wiele realnych przejawów tej przemocy nie jest do niej zaliczanych. Brak w tym względzie zarówno badań akademickich, nieliczne sa też publikacje prasowe. Poza tym, co najważniejsze, zachowania przemocowe sa dyskutowane przede wszystkim w aspekcie kobiety jako ofiary, bo kobieta jako sprawczyni przemocy ekonomicznej nie budzi prawie żadnego zainteresowania.

19 J. Tracz-Dral, op. cit., s. 15-16.

20 Po raz pierwszy przemoc ekonomiczną opisano jako wynik badań amerykańskiego zespołu realizujacego „Domestic Abuse Intervention Project” w 1981 r. w miejscowości Duluth [Dostęp: 04.03.2017]. Dostępny w World Wide Web: $<$ http:// bit.ly/1izPT21>.

21 A. Chełstowska, M. Druciarek, A. Niżyńska, op. cit., s. 18; cyt. za: J. Raphael, Keeping Women Poor: How Domestic Violence Prevents Women From Leaving Welfare and Entering the World of Work, in Battered Women, Children, and Welfare Reform, Thousand Oaks 1999; S. Lloyd, N. Taluc, The Effects of Male Violence on Female Employment, „Violence Against Women” 1999, Vol. 5, Iss. 4, p. 370-392.

22 A. Chełstowska, M. Druciarek, A. Niżyńska, op. cit., s. 19. 
$\mathrm{Na}$ tle przedstawionych uwag skonkretyzowano następujące pytania badawcze: Czy w Polsce istnieje kobieca przemoc ekonomiczna? Jaka jest skala tej przemocy?

\section{Polskie badania nad przemocą ekonomiczną}

W Polsce praktycznie nie prowadzono badań nad przemoca ekonomiczna, a jej zagadnienia występuja $\mathrm{w}$ projektach marginalnie, przy okazji badań nad przemocą w ogóle.

W 2010 r. Centrum Badania Opinii Społecznej, na zlecenie Ministerstwa Pracy i Polityki Socjalnej, podjęło badania nad zjawiskiem przemocy $\mathrm{w}$ rodzinie wobec kobiet i wobec mężczyzn w Polsce. Ich wyniki opublikowano w dwóch częściach - część pierwsza jako raport $z$ badań ogólnopolskich i część druga jako raport $z$ badań profesjonalistów. Ogólnopolski sondaż za pomoca wywiadu telefonicznego wspomaganego komputerowo realizowano na grupie 3 tys. respondentów (1500 kobiet i 1500 mężczyzn). $\mathrm{Na}$ podstawie tych samych narzędzi uzyskano wypowiedzi pięciuset profesjonalistów (po stu funkcjonariuszy Policji, kuratorów sądowych, pracowników ochrony zdrowia, pracowników socjalnych i pracowników komisji rozwiązywania problemów alkoholowych). W 2014 r. badania nad przemoca w rodzinie zostały powtórzone, a ich wyniki porównano $z$ tymi z 2010 r. W badaniach tych znalazła się kwestia przemocy ekonomicznej, w tym również kobiecych zachowań przemocowych na tle finansowym $z$ perspektywy świadka pośredniego, ofiary, sprawczyni oraz świadka bezpośredniego.

\section{Przemoc ekonomiczna $z$ perspektywy świadka pośredniego}

Ocena wiedzy respondentów, tak zwanych świadków pośrednich (Tabela 2), na temat przemocy ekonomicznej, w której ofiarami byli mężczyźni, pokazuje, że zarówno w 2010, jak i w 2014 r. większość badanych nie słyszała o występowaniu takiej przemo- 
cy. $Z$ kolei odsetek badanych posiadajacych wiedzę na ten temat w ciagu czterech lat dzielacych te dwa projekty badawcze istotnie zmalał - z 11,6 do 7,4\% ${ }^{23}$.

Tabela 2. Odsetek odpowiedzi na pytanie „Czy Pan/i osobiście zna - w swoim otoczeniu, sasiedztwie - takie rodziny, o których Pan/i słyszał/a lub wie, że dochodzi w nich do różnych form przemocy ekonomicznej wobec mężczyzn?”

\begin{tabular}{|c|c|c|c|}
\hline \multirow{2}{*}{ Rok } & \multirow{2}{*}{} & \multicolumn{2}{|c|}{ Udzial procentowy odpowiedzi } \\
\cline { 3 - 4 } & & Tak & Nie \\
\hline 2010 & $\mathrm{n}=3000$ & 11,6 & 88,4 \\
\hline 2014 & $\mathrm{n}=2984$ & 7,4 & 92,6 \\
\hline
\end{tabular}

Źródło: M. Miedzik, J. Godlewska-Szurkowa, wspótprac. J. Rutkowski, op. cit., wykres 28 , s. 43.

Sformułowanie pytania jasno określa płeć ofiary. Niestety w pytaniu nie wskazano płci sprawcy, co oznacza, że pod tym względem należy brać pod uwagę zarówno mężczyzn, jak i kobiety. Sprawca może być mieszkająca we wspólnym gospodarstwie kobieta lub mężczyzna (np. ojciec). Bardziej jednak prawdopodobny $\mathrm{w}$ takich przypadkach jest udział kobiet (głównie partnerek) jako sprawczyń przemocy ekonomicznej.

\section{Przemoc ekonomiczna z perspektywy ofiary}

Deklaracje wyrażane przez ofiary w czasie badania (Tabela 3) pokazują, że odsetek mężczyzn doświadczających przemocy ekonomicznej w pierwszym i drugim badaniu zmalał o 1,4 punktu

23 M. Miedzik, J. Godlewska-Szurkowa, współprac. J. Rutkowski, Badania porównawcze oraz diagnoza wystepowania przemocy $w$ rodzinie wśród osób dorosłych $i$ dzieci, $z$ podziałem na poszczególne formy przemocy wraz $z$ opisem charakterystyki ofiar przemocy $i$ sprawców, Warszawa 2014, s. 43 [Dostęp: 06.03.2017]. Dostępny w World Wide Web: <http://bit.ly/2rjLBSt>. 
procentowego. Wypowiedzi respondentów wskazuja, że na przestrzeni lat 2010-2014 wystapił niewielki spadek zjawiska przemocy ekonomicznej wobec mężczyzn.

Tabela 3. Odsetek mężczyzn doświadczających w ciagu swojego życia przemocy ekonomicznej

\begin{tabular}{|c|c|c|c|}
\hline \multirow{2}{*}{ Rok } & & \multicolumn{2}{|c|}{ Udzial procentowy odpowiedzi } \\
\cline { 2 - 4 } & & Tak & Nie \\
\hline 2010 & $\mathrm{n}=1430$ & 5,6 & 94,4 \\
\hline 2014 & $\mathrm{n}=1382$ & 4,2 & 95,8 \\
\hline
\end{tabular}

Źródło: M. Miedzik, J. Godlewska-Szurkowa, wspótprac. J. Rutkowski, op. cit., wykres 76, s. 73.

Odniesienie danych uzyskanych od ofiar (Tabela 3) do wyników uzyskanych od świadków pośrednich (Tabela 2) wskazuje, że średnio dwa razy mniej ofiar - mężczyzn przyznaje się, że żyje w sytuacji domowej przemocy ekonomicznej, lub, że świadkowie pośredni średnio dwa razy częściej traktuja sytuację domowa w kategoriach przemocy ekonomicznej. Głównym powodem takiego podejścia może być brak wiedzy na temat tego rodzaju przemocy, a w szczególności jej symptomów.

\section{Kobieca przemoc ekonomiczna z perspektywy sprawczyni}

W 2014 r. (Tabela 4) zaledwie 0,3\% respondentek potwierdziło, że w gospodarstwie domowym dochodziło do przemocy ekonomicznej $z$ ich winy. Stanowi to istotnie niższy odsetek niż w 2010 r., gdy 3,1\% respondentek przyznało się do stosowania przemocy ekonomicznej, co oznacza dziesięć razy mniejsze nasilenie zjawiska. Pod tym względem dane te korespondują $z$ obserwacjami świadków pośrednich i doświadczeniami ofiar. 
Tabela 4. Odsetek kobiet będących w ciagu swojego życia sprawcami przemocy ekonomicznej

\begin{tabular}{|c|c|c|c|}
\hline \multirow{2}{*}{ Rok } & & \multicolumn{2}{|c|}{ Udzial procentowy odpowiedzi } \\
\cline { 3 - 4 } & & Tak & Nie \\
\hline 2010 & $\mathrm{n}=1568$ & 3,1 & 96,9 \\
\hline 2014 & $\mathrm{n}=1455$ & 0,3 & 99,7 \\
\hline
\end{tabular}

Źródło: M. Miedzik, J. Godlewska-Szurkowa, wspótprac. J. Rutkowski, op. cit., wykres 91, s. 79 .

Bezpośrednie przyznanie się do stosowania przemocy ekonomicznej przez kobietę daje pewna możliwość oceny skali problemu. Pozostaje tu jednak znowu pewien margines błędu, ponieważ autorzy projektu nie określili rodzajów ekonomicznych zachowań przemocowych. Mogło to powodować pominięcie wielu działań faktycznie wchodzacych do katalogu przemocy ekonomicznej, ale nieuświadamianych sobie przez sprawczynie.

\section{Kobieca przemoc ekonomiczna z perspektywy świadka bezpośredniego}

W 2010 r. 6,6\% respondentów uznało się za świadków bezpośrednich kobiecej przemocy ekonomicznej (Tabela 5), ale w 2014 r. było to już tylko 3,7\% badanych.

Udział kobiet wśród respondentów wyrażających pozytywna deklarację jest zauważalnie większy w 2010 r. (stosunek $\mathrm{K}: \mathrm{M}=$ $7,7 \%: 5,4 \%$ ). W następnym badaniu (2014) różnica ta jest już niewielka (stosunek $\mathrm{K}: \mathrm{M}=3,9 \%: 3,5 \%$ ). 
Tabela 5. Odsetek osób będących bezpośrednimi świadkami przemocy ekonomicznej

\begin{tabular}{|c|c|c|c|c|c|c|c|}
\hline \multirow{3}{*}{ Rok } & \multirow{3}{*}{$\begin{array}{l}\text { Liczba } \\
\text { respondentów }\end{array}$} & \multicolumn{6}{|c|}{ Udzial procentowy odpowiedzi } \\
\hline & & \multicolumn{3}{|c|}{ Tak } & \multicolumn{3}{|c|}{ Nie } \\
\hline & & Ogólem & $\mathbf{K}$ & $\mathbf{M}$ & Ogólem & $\mathbf{K}$ & $\mathbf{M}$ \\
\hline 2010 & $\begin{array}{l}\mathrm{n}=2943 \\
\mathrm{~K}=1549 \\
\mathrm{M}=1393\end{array}$ & 6,6 & 7,7 & 5,4 & 93,4 & 92,3 & 94,6 \\
\hline 2014 & $\begin{array}{l}\mathrm{n}=2725 \\
\mathrm{~K}=1468 \\
\mathrm{M}=1257\end{array}$ & 3,7 & 3,9 & 3,5 & 96,3 & 96,1 & 96,5 \\
\hline
\end{tabular}

Źródło: M. Miedzik, J. Godlewska-Szurkowa, wspótprac. J. Rutkowski, op. cit., wykresy 104, 105, 106, s. 84-85.

Podobnie jak w poprzednim pytaniu, należy przyjać, że uzyskane wskazania moga odzwierciedlać faktyczna sytuację, znowu jednak $z$ zastrzeżeniem pominięcia niektórych ekonomicznych zachowań przemocowych kobiety w stosunku do partnera lub innych osób (ludzi niepełnosprawnych, starszych, chorych) z powodu braku wiedzy świadka na ten temat.

\section{Stopień pokrewieństwa sprawczyni przemocy ekonomicznej z perspektywy ofiary - mężczyzny}

W pytaniu o płeć sprawców przemocy ekonomicznej 58\% ofiar mężczyzn wskazywało kobietę. Dane te korespondują $z$ wynikami wywiadu ze świadkami pośrednimi oraz ofiarami - mężczyznami, ujętymi w Tabeli 1 i Tabeli 2 . 
Tabela 6. Stopień pokrewieństwa sprawczyni z perspektywy ofiary mężczyzny w badaniach z 2010 r.

\begin{tabular}{|c|c|c|}
\hline & Stopień pokrewieństwa & Wskazania w \%* \\
\hline 1. & Żona & 34 \\
\hline 2. & Partnerka & 4 \\
\hline 3. & Matka (macocha) & 21 \\
\hline 4. & Córka (pasierbica) & 2 \\
\hline 5. & Babcia & 1 \\
\hline 6. & Siostra & 3 \\
\hline 7. & Teściowa & 1 \\
\hline 8. & Szwagierka & 1 \\
\hline 9. & Inna kobieta $z$ rodziny & 3 \\
\hline 10. & Inna kobieta niespokrewniona & 1 \\
\hline
\end{tabular}

* Liczby nie sumuja się do stu, ponieważ w tabeli źródłowej uwzględniano też stopień pokrewieństwa mężczyzn jako sprawców przemocy ekonomicznej, a dodatkowo ofiary czasem zaznaczały więcej niż jedną osobę jako sprawców przemocy ekonomicznej.

Źródło: Diagnoza zjawiska przemocy $w$ rodzinie $w$ Polsce wobec kobiet $i$ wobec mężczyzn, Część I - Raport z badań ogólnopolskich, Warszawa 2010, s. 119 [Dostęp: 6.03.2017]. Dostępny w World Wide Web: <http://bit.ly/2qFwzop>.

Wskazania ofiar - mężczyzn $z$ badań przeprowadzonych w 2010 r. pokazuja, że - z uwagi na stopień pokrewieństwa sprawczynia przemocy ekonomicznej najczęściej jest żona (Tabela 6). Na drugim miejscu pod względem liczebności wskazań znalazła się matka lub macocha, a następnie partnerka, siostra i inna kobieta $z$ rodziny. Pozostałe sprawczynie, jak córka i pasierbica, babcia, teściowa, szwagierka czy nawet inna kobieta niespokrewniona, były wymieniane sporadycznie. Niemniej pojawienie się tej ostatniej grupy $\mathrm{w}$ rankingu wskazuje, że stosowanie przemocy ekonomicznej przez kobietę nie jest związane wyłącznie $z$ jej rola pełniona $\mathrm{w}$ rodzinie. Badania z $2014 \mathrm{r}$. nie uwzględniły stopnia pokrewieństwa sprawcy przemocy i ofiary, nie można zatem dokonać porównania. 


\section{Badania z 2010 r. Raport profesjonalistów}

W raporcie profesjonalistów $41 \%$ ankietowanych policjantów dostrzega wzrost liczby kobiet jako sprawczyń przemocy ekonomicznej. Tę kategorię jako wzrostową ocenia nawet $46 \%$ badanych kuratorów. Pracownicy ochrony zdrowia zauważaja wzrost problemu na poziomie $43 \%$ wskazań. Najmniejszy wzrost liczby sprawczyń - kobiet w obrębie przemocy ekonomicznej zanotowali pracownicy socjalni, ponieważ tylko $32 \%$ ankietowanych. Ostatnią grupa badanych profesjonalistów byli pracownicy Gminnych Komisji Rozwiązywania Problemów Alkoholowych (GKRPA), w której to grupie $41 \%$ respondentów wskazywało wzrost liczby kobiet stosujacych przemoc ekonomiczną ${ }^{24}$.

Bezpośrednie doświadczenia profesjonalistów z przypadkami przemocy ekonomicznej są znacznie mniejsze, ponieważ wskazania mieszcza się w przedziale od 20 do $36 \%$. Najwięcej przykładów sprawstwa przemocy ekonomicznej przez kobietę $z$ własnej praktyki wskazuja pracownicy GKRPA oraz policjanci 25 .

Badania profesjonalistów pozwoliły wyodrębnić niektóre cechy sylwetki sprawczyni przemocy ekonomicznej: kobieta starsza od ofiary, spokrewniona $z$ ofiara, niebędąca pod wpływem alkoholu. Badani podkreślali, że środowiskiem kobiecej przemocy ekonomicznej jest normalna, przeciętna rodzina ${ }^{26}$.

\section{Badania z 2015 r.}

Na przełomie 2014/2015 r. Instytut Spraw Publicznych zrealizował projekt diagnozujacy zjawisko przemocy ekonomicznej $\mathrm{w}$ Polsce. Skupiono się w nim na przemocy w związkach intym-

\footnotetext{
${ }^{24}$ Diagnoza zjawiska przemocy $w$ rodzinie $w$ Polsce wobec kobiet $i$ wobec męzczyzn, Część II - Raport z badań profesjonalistów, Warszawa 2010, tabele s. 28, 30, 32, 34, 36 [Dostęp: 06.03.2017]. Dostępny w World Wide Web: $<$ http:// bit.ly/2qFornL $>$.

25 Ibidem, tabele s. 50 i n.

26 Ibidem, tabele s. 76, 79, 81, 84.
} 
nych, uwzględniając także kwestie alimentacyjne, jego wada jest jednak to, że posługuje się wyłącznie modelem kobieta - ofiara i mężczyzna - sprawca. Badania metoda wywiadów wspomaganych komputerowo (CAP) przeprowadzono na grupie tysiąca osób w wieku 15 lat i więcej. Natomiast niezaprzeczalna zaleta projektu było zastosowanie konkretnych przykładów zachowań przemocy ekonomicznej, co pozwoliło respondentom jasno odnieść się do wskazanych problemów, a badaczom realnie ocenić skalę tej przemocy.

Badania te pokazały przede wszystkim, że respondenci wykazywali odmienna akceptację dla różnych przejawów przemocy ekonomicznej, przy czym poziom akceptacji okazał się silnie zależny od płci, miejsca zamieszkania i poziomu wykształcenia. Informacje zebrane $z$ pytania o osobiste doświadczenie przemocy ekonomicznej lub obserwację tego typu zachowań w najbliższym otoczeniu pozwoliły określić występowanie i skalę zjawiska. Okazało się, że 19-26\% respondentów obserwowało w swoim otoczeniu zachowania świadczące o niewłaściwych relacjach zwiazanych $z$ podłożem ekonomicznym. $Z$ kolei osobiście przemocy ekonomicznej doświadczyło od 6 do $12 \%$ respondentów, w zależności od rodzaju zachowania przemocowego. Wyraźnie dostrzegalna była kobieca przemoc ekonomiczna, ponieważ $11 \%$ respondentów mężczyzn deklarowało doświadczanie podejmowania ważnych decyzji finansowych przez partnerkę bez uzgodnienia ${ }^{27}$.

\section{Podsumowanie}

Przemoc ekonomiczna jest zjawiskiem patologicznym o podłożu psychologicznym. Głównym celem sprawcy jest psychiczne uzależnienie oraz upokorzenie. Narzędziem do manipulowania ofiara, do podporządkowania i uległości jest kontrola budżetu domowego. Ta forma przemocy często występuje razem $z$ innymi formami. Przemoc ekonomiczna nie pozostawia widocznych śla-

27 A. Chełstowska, M. Druciarek, A. Niżyńska, op. cit., s. 32 i n. 
dów, jest niedostrzegana przez otoczenie, jest więc przezroczysta. Pojawia się w związkach bez względu na sytuację materialna, wykształcenie i wiek.

Jak pokazuja dotychczasowe polskie badania społeczne, w których kobieca przemoc ekonomiczna występuje tylko na marginesie projektów dotyczacych innych rodzajów przemocy lub ukazuje mężczyznę jako sprawcę, tego typu zachowania przemocowe podejmowane przez kobiety w Polsce występuja i sa obecne w różnego typu relacjach rodzinnych. Sa elementem przemocy domowej w Polsce. Kobiety dopuszczaja się tego rodzaju zachowań na tle finansowym przede wszystkim w stosunku do partnera, ale także do osób nieporadnych, wymagających zrozumienia i opieki.

Wskazania uzyskane od ofiar pokazuja, że skala kobiecej przemocy ekonomicznej jest zapewne duża ${ }^{28}$. Niewatpliwie istnieje pokaźna liczba jej sprawczyń, co powoduje trudność w ocenie jej faktycznych rozmiarów. Przy tak minimalnej liczbie i zasięgu badań niemożliwa jest też do określenia chociażby przybliżona sylwetka sprawczyni.

Według deklaracji ofiar - mężczyzn uzyskanych w ramach polskich badań społecznych doświadczanie przemocy ekonomicznej w 2010 r. było na poziomie 5,6\%, w 2014 r. - 4,2\%, ale w 2015 r. osiagnęło już wartość 11\%. Dane te wskazują, że konieczne jest podjęcie badań ukierunkowanych wyłącznie na te formę przemocy i objęcie nimi szerokich kręgów społeczeństwa na różnych poziomach zamożności. Powinny być one prowadzone w dwóch etapach. Najpierw jako szeroko zakrojona eksploracja ilościowa, dedykowana wyłącznie przemocy ekonomicznej wobec mężczyzn. W drugim etapie zaś dociekania powinny objąć wyselekcjonowana grupę mężczyzn doświadczających przemocy ekonomicznej, której sprawca jest kobieta.

\footnotetext{
28 Uwaga autorki: gdy $\mathrm{w}$ trakcie wykładu mówiła o przemocy ekonomicznej w związkach intymnych, podając jej przejawy, studenci mężczyźni (grupa liczyła 22 osoby, w tym 15 panów) zaczęli bezceremonialnie wskazywać jedną $z$ koleżanek i głośno komentować jej zachowania w stosunku do partnera, polegające na „drastycznym” kontrolowaniu jego wydatków.
} 


\section{Bibliografia}

\section{Opracowania}

Adams Adrienne E., Sullivan Cris M., Bybee Deborah, Greeson Megan R., Development of the Scale of Economic Abuse, „Violence Against Women" 2008, Vol. 14, Iss. 5 [Dostęp: 06.03.2017]. Dostępny w World Wide Web: <http://bit.ly/2qAaXyo>.

Browne Kevin, Herbert Martin, Zapobieganie przemocy $w$ rodzinie, Warszawa: Wydawnictwa Szkolne i Pedagogiczne, 1999, ISBN 83-0207441-1.

Gotfryd Paulina, Kiedy bije kobieta. Doświadczenia brytyjskie, „Niebieska Linia” 2010, nr 4 [Dostęp: 07.01.2017]. Dostępny w World Wide Web: <http:/ / bit.ly/2qFBc1G>.

Kotlarska-Michalska Anna, Społeczne role kobiet, „Edukacja Humanistyczna" 2011, nr 1, ISSN 1507-4943.

Kowalska Anna, Słaba płeć? - Przemoc stosowana przez kobiety [w:] Przemocy mówimy dość, red. Marian Piotr Krysiak, Maków Mazowiecki: Powiat Makowski i Komenda Powiatowa Policji, 2010.

Leśniewska Grażyna, Przemoc ekonomiczna wobec kobiet - przeźroczysty problem [w:] Gospodarka przestrzenna: aktualne aspekty polityki spoŁeczno-gospodarczej i przestrzennej, red. Jacek Potocki, Jerzy Ładysz, Wrocław: Wydawnictwo Uniwersytetu Ekonomicznego, 2016.

Lipowska-Teutsch Anna, Rodzina a przemoc, Warszawa: Państwowa Agencja Rozwiąywania Problemów Alkoholowych, 1993, ISBN 8385284184.

Lloyd Susan, Taluc Nina, The Effects of Male Violence on Female Employment, „Violence Against Women” 1999, Vol. 5, Iss. 4.

Piatek Katarzyna, Być kobieta $w$ Polsce $w$ XXI wieku - blaski i cienie [w:] Między tradycja a nowoczesnością. Współczesna kobieta polska $z$ perspektywy socjologicznej, red. Ewa Jurczyńska-McCluskey, Katarzyna Piątek, Bielsko-Biała: Akademia Techniczno-Humanistyczna, 2006.

Pospiszyl Irena, Przemoc $w$ rodzinie, Warszawa: Wydawnictwa Szkolne i Pedagogiczne, 1998, ISBN 83-0205556-5.

Raphael Jody, Keeping Women Poor: How Domestic Violence Prevents Women From Leaving Welfare and Entering the World of Work, in Battered Women, Children, and Welfare Reform, red. Ruth A. Brandwein, Thousand Oaks, CA, 1999. 


\section{Akty prawne}

Konwencja Rady Europy, Konwencja o zapobieganiu $i$ zwalczaniu przemocy wobec kobiet $i$ przemocy domowej, tłumaczenie przygotowane na zlecenie Kancelarii Prezesa Rady Ministrów [Dostęp: 3.03.2017]. Dostępny w World Wide Web: <http://bit.ly/2gRTPOU>.

\section{Raporty z badań}

Chełstowska Agata, Druciarek Małgorzata, Niżyńska Aleksandra, Przemoc ekonomiczna w zwiazkach. Diagnoza zjawiska i dyskusja o przeciwdziałaniu, Warszawa: Instytut Spraw Publicznych, 2015 [Dostęp: 06.03.2017]. Dostępny w World Wide Web: <http://bit.ly/2qAaXyo>.

Diagnoza zjawiska przemocy $w$ rodzinie $w$ Polsce wobec kobiet $i$ wobec mężczyzn, Część I - Raport z badań ogólnopolskich, Warszawa: Ministerstwo Pracy i Polityki Społecznej, 2010 [Dostęp: 06.03.2017]. Dostępny w World Wide Web: <http://bit.ly/2qFwzop>.

Diagnoza zjawiska przemocy $w$ rodzinie $w$ Polsce wobec kobiet $i$ wobec mężczyzn, Część II - Raport z badań profesjonalistów, Warszawa: Ministerstwo Pracy i Polityki Społecznej, 2010 [Dostęp: 6.03.2017]. Dostępny w World Wide Web: <http://bit.ly/2qFornL>.

Miedzik Monika, Godlewska-Szurkowa Justyna, współpraca Jakub Rutkowski, Badania porównawcze oraz diagnoza wystepowania przemocy $w$ rodzinie wśród osób dorosłych $i$ dzieci, $z$ podziałem na poszczególne formy przemocy wraz z opisem charakterystyki ofiar przemocy i sprawców, Warszawa: Ministerstwo Pracy i Polityki Społecznej, 2014 [Dostęp: 06.03.2017]. Dostępny w World Wide Web: $<$ http:/ / bit.ly/2rjLBSt>.

Przemoc $w$ rodzinie wobec osób starszych i niepetnosprawnych. Poradnik dla pracowników pierwszego kontaktu, red. Dorota Jaszczak-Kuźmińska, Katarzyna Michalska, Warszawa: Ministerstwo Pracy i Polityki Społecznej, 2010 [Dostęp: 06.03.2017]. Dostępny w World Wide Web: <https://ms.gov.pl/Data/Files/_public/ppwr/poradnik.pdf>.

Przemoc $w$ rodzinie a wymiar sprawiedliwości, Warszawa: Fundacja Centrum Praw Kobiet, 2005, ISBN 83-91332-2-1 [Dostęp: 6.03.2017]. Dostępny w World Wide Web: <http://bit.ly/2qAzRKa>.

Tracz-Dral Jagoda, Przemoc ekonomiczna, opracowanie tematyczne OT-639, Warszawa: Kancelaria Senatu 2015 [Dostęp: 6.03.2017]. Dosteppny w World Wide Web: <http://bit.ly/2raz5GB>. 


\section{Zasoby internetowe}

Domestic Abuse Intervention Project [Dostęp: 04.03.2017]. Dostępny w World Wide Web: <http://bit.ly/1izPT2l>.

Od przemocy ekonomicznej do niezależności, red. Małgorzata Bladowska-Wrzodak [Dostęp: 07.01.2017]. Dostępny w World Wide Web: $<$ http://bit.ly/2qA83d8>.

Słownik języka polskiego [Dostęp: 06.03.2017]. Dostępny w World Wide Web: <http://sjp.pwn.pl/sjp/przemoc;2510670.html>.

Statystyka - Policja. Przemoc $w$ rodzinie. Dane za rok 2016 [Dostęp: 31.11.2016]. Dostępny w World Wide Web: <http://bit.ly/1nAcMjB>. Sygit Ewa, Ossowski Roman, Przemoc wobec osób starszych ze względu na ich wiek, płeć $i$ wykształcenie, "Gerontologia Polska” [online] 2008, nr 3, ISSN 1425-4956 [Dostęp: 06.03.2017]. Dostępny w World Wide Web: <http://bit.ly/2sdtL3S>. 